of alpha-methyl-D-glucoside transport by rat kidney cortex slices. Biochim Biophys Acta 291:519

32. Silverman M 1976 Glucose transport in the kidney. Biochim Biophys Acta 457:303

33. Silverman M, Black J 1975 High affinity phlorizin receptor sites and their relation to the glucose transport mechanism in the proximal tubule of the dog kidney. Biochim Biophys Acta 394:10

34. Spitzer A, Edelmann CM Jr 1971 Maturational changes in pressure gradients for glomerular filtration. Am J Physiol 221:1431

35. Spitzer A 1982 The Kidney during development. Masson Publishing, New York

36. Turner RJ, Silverman M 1978 Sugar uptake into brush border vesicles from dog kidney. I. Specificity. Biochim Biophys Acta 507:305
37. Weil WB Jr 1955 Evaluation of renal function in infancy and childhood. Am J Med Sci 229:678

38. The authors wish to acknowledge the excellent technical assistance provided by Mrs. Louise M. Pepe.

39. Requests for reprints should be addressed to: Dr. John W. Foreman, The Joseph Stokes, Jr. Research Institute, The Children's Hospital of Philadelphia, 34th St. and Civic Center Blvd., Philadelphia, PA 19104.

40. This work was supported by Grant AM 10894 from the National Institutes of Health. Presented in part before the Society for Pediatric Research, April 29, 1982, San Antonio, Texas.

41. Received for publication May 12, 1983.

42. Accepted for publication October 21,1983

\title{
Immunoregulation in an Isolated 12-year-old Boy with Congenital Severe Combined Immunodeficiency
}

\author{
VELMA L. PASCHALL, LEWIS A. BROWN, E. CLINTON LAWRENCE, ROBIN A. KAROL, \\ EVA LOTZOVA, BETTY S. BROWN, AND WILLIAM T. SHEARER ${ }^{(33)}$ \\ Departments of Pediatrics, Medicine, Microbiology, and Immunology, Baylor College of Medicine, the Allergy \\ and Immunology Service, Texas Children's Hospital, and the Department of Clinical Immunology and \\ Biological Therapeutics, the M. D. Anderson Hospital, Houston, Texas, USA
}

\section{Summary}

We report the evaluation of in vitro immunoregulation in a 12year-old untreated boy with severe combined immunodeficiency (SCID). Severely hypogammaglobulinemic, the patient was incapable of a specific antibody response to either natural substances or administered antigens. Ficoll-Hypaque-isolated peripheral blood mononuclear cells (MNL) from the patient failed to respond to pokeweed mitogen (PWM) with the normal increment in immunoglobulin-secreting cells, as measured by a reverse hemolytic plaque assay. Since the patient was lymphopenic, his MNL were relatively enriched for monocytes (range $=51-81 \%$ ). Removal of phagocytic cells or the addition of unrelated irradiated helper $\mathbf{T}$ lymphocytes resulted in enhanced, but still suboptimal response to $\mathrm{PWM}$, suggesting some intrinsic defect in B lymphocyte function. Co-culture of patient MNL with normal MNL resulted in marked suppression (12\% of predicted) of PWM-induced Ig-secreting cells. Suppressor activity was unaffected by prior irradiation of patient MNL, but was substantially reversed $(99 \%$ of predicted) by removal of his phagocytic cells, whereas the combination of the two procedures further reversed suppression (184\% of predicted). The patient's MNL consistently demonstrated subnormal percentages of $\mathrm{T} 3+$ and $\mathrm{T4+}$ cells and subnormal to low normal percentages of $\mathrm{T8}+$ cells. These data suggest both an intrinsic defect in B lymphocyte function, and a relative excess of monocytes which could further inhibit Ig secretion by B lymphocytes. Natural killer (NK) cell function was characterized by normal target cell binding by NK cells but severely depressed NK cell cytotoxicity.

\section{Abbreviations}

SCID, severe combined immunodeficiency

MNL, mononuclear cells
PWM, pokeweed mitogen

NK, natural killer

HBSS, Hanks' balanced salt solution

Ig-SC, immunoglobin-secreting cells

HEPES, 4-(2-hydroxyethyl)-1-piperazineethanesulfonic acid

EBV, Epstein-Barr virus

PHA, phytohemagglutinin

Con A, concanavalin A

SK-SD, streptokinase-streptodornase

WBC, white blood cells

SCID encompasses a heterogeneous group of congenital disorders which manifest varying degrees of dysfunction of both $B$ and $T$ lymphocytes (28). Although the majority of patients lack adequate numbers and function of both $T$ and $B$ lymphocytes, a minority of patients has been identified with normal circulating numbers of these cell populations $(6,10,21,22)$. The basis for this paradox is believed to be the abnormal differentiation of $\mathbf{B}$ and $T$ cell precursors (22). Inadequate numbers of helper $T$ cells have been implicated in a few patients $(4,24)$ and several authors have also suggested a role for excessive numbers of suppressor $\mathrm{T}$ cells, which has been documented in at least one case (21). Certainly other forms of immunodeficiency, including subgroups of patients with common variable hypogammaglobulinemia, selective IgA deficiency, and X-linked agammaglobulinemia, have been described with increased numbers or function of suppressor T lymphocytes $(1,25,27)$. An intrinsic B cell abnormality in SCID has also been observed (7).

We have had the opportunity of serially evaluating immune functions in a 12-year-old white male with SCID, who has been maintained since birth in a gnotobiotic environment. This patient has been the subject of multiple investigations regarding 
diverse aspects of his early (birth to 4 years of life) immune system $(18-20,26,29)$, but no assessment has yet been made of $\mathrm{B}$ cell secretion of $\mathrm{Ig}$, monocyte function, immunoregulatory $\mathrm{T}$ cell subsets, or NK cell function. Using classic as well as more recent immunological techniques, we have identified and partially characterized defects in B cell, T cell, as well as monocyte and NK cell functions.

\section{MATERIALS AND METHODS}

Study Subjects. The patient studied was a 12-year-old male with SCID. Although exposed to at least 35 species of microorganisms in his isolator system (29), the patient has never sustained an infection except for transient Staphylococcal epidermidis bacteremia associated with the swallowing of a coin when he was 7 years old. Aside from receiving transfer factor as an infant (29), the patient has not been given any mode of immunotherapy. Normal healthy children and adults served as controls for these experiments. All blood specimens were obtained with the written consent of parents or individual using forms approved by the Institutional Review Boards for Human Research of the Baylor College of Medicine and Texas Children's Hospital.

Isolation and Preparation of Peripheral Blood Mononuclear Cells. Blood was collected by sterile technique in heparinized containers and total MNL were isolated by Ficoll-Hypaque (Pharmacia Fine Chemicals, Piscataway, NJ) gradient separation as previously described (2). In co-culture experiments, MNL suspensions were irradiated (total dose of 2500 rads) to inactivate radiosensitive subpopulations (suppressor $\mathrm{T}$ lymphocytes and $\mathrm{B}$ lymphocytes) and/or reacted with iron carbonyl in solution for $1 \mathrm{~h}$ to remove phagocytic cells (13). Those cells which phagocytized the iron (predominantly monocytes) were removed with a magnet, and the resultant phagocyte-depleted suspension was recentrifuged through Ficoll-Hypaque as before.

Enumeration of T Cells. T cells were enumerated by determining the ability of purified MNL to form rosettes with sheep red blood cells according to the method of Wybran et al. (30).

Enumeration of $B$ Cells. Enumeration and characterization of $B$ cells in the MNL suspensions were performed by the method of Greaves et al. (9) using fluoresceinated goat $\left(\mathrm{Fab}^{\prime}\right)_{2}$ antihuman IgG, IgA, IgD, IgM and polyvalent anti-human $\operatorname{Ig}$ (Cappel Laboratories, Cochranville, PA) and a Leitz Ortholux fluorescence microscope under episcopic illumination.

Determination of Serum Ig Levels. Serum Ig (IgG, IgA, IgM) levels were determined by kinetic immunonephelometry with the Beckman Immunochemical System (Beckman Instruments, Fullerton, CA). Serum IgE levels were determined with the Phadebas IgE PRIST radioimmunoassay (Pharmacia Diagnostics, Piscataway, NJ).

Lymphocyte Transformation Studies. MNL were suspended at a cell density of $1 \times 10^{6}$ cells $/ \mathrm{ml}$ in Medium 199 (GIBCO, Grand Island, NY) plus heat-inactivated $15 \%$ pooled human serum, incubated in 200- $\mu$ l volumes in microtiter plates (Flow Laboratories, McLean, VA) in the presence and absence of mitogens for $72 \mathrm{~h}$ at $37^{\circ} \mathrm{C}(5)$. The mitogens employed included three concentrations each of PHA (Burroughs Wellcome, Research Triangle Park, NC), Con A (Calbiochem Corp., San Diego, CA), and PWM, (GIBCO). During the last $18 \mathrm{~h}$ of culture, tritiated thymidine (Amersham-Searle, Arlington Heights, IL) was added to the cultures at a final radioactivity concentration of $10 \mu \mathrm{Ci}$ / $\mathrm{ml}$. A similar protocol was employed for specific antigen stimulation studies with the only modification being an incubation time of $120 \mathrm{~h}$ prior to the addition of $\left[{ }^{3} \mathrm{H}\right] \mathrm{dThd}$. The antigens employed were three concentrations each of dermatophyton $\mathrm{O}$, an undiluted extract from Candida albicans (Hollister-Stier Lab., Dallas, TX), fluid tetanus toxoid (Wyeth Laboratories, Dallas, TX), and streptokinase-streptodornase (SK-SD, Lederle Laboratory Div., American Cyanamid Co., Pearl River, NY).

In mixed leukocyte cultures, the stimulator cells were treated with mitomycin C (Sigma Chemical, St. Louis, MO) at a con- centration of $500 \mu \mathrm{g} / \mathrm{ml}$ for $30 \mathrm{~min}$ at $37^{\circ} \mathrm{C}$. Responder cells were divided into equal aliquots, one of which was incubated on plastic Petri dishes for $1 \mathrm{~h}$ at $37^{\circ} \mathrm{C}$ in a humid chamber in order to remove adherent cells (predominantly monocytes). The stimulator and both aliquots of responder cells were suspended at a cell density of $5 \times 10^{5}$ cells/ml in Medium 199 plus heatinactivated $15 \%$ pooled human serum. One hundred $\mu$ l of the stimulator cell suspension were added to $100 \mu \mathrm{l}$ of both responder cell suspensions in wells of the microtiter plate. After an incubation of $120 \mathrm{~h}$ at $37^{\circ} \mathrm{C}$, each well was pulsed with $20 \mu \mathrm{l}$ of $\left[{ }^{3} \mathrm{H}\right]$ dThd $(100 \mu \mathrm{Ci} / \mathrm{ml})$. The plates were incubated overnight and harvested.

Identification of $T$ Cell Subsets. Freshly prepared MNL were analyzed by indirect immunofluorescence. Samples $\left(1 \times 10^{6}\right.$ cells) were washed 3 times in HBSS (M. A. Bioproducts, Walkersville, MD), suspended in $100 \mu \mathrm{l}$ of HBSS, and $5 \mu \mathrm{l}$ of monoclonal antibodies to T3, T4, T6, T8, T10, T11, Ia1, B1, and M1 (Ortho Pharmaceuticals, Raritan, NJ) or control ascites were added. The samples were incubated for $30 \mathrm{~min}$ on ice and washed twice with cold HBSS, and $10 \mu \mathrm{l}$ of fluorescein-labeled rabbit or goat anti-mouse IgG (Cappel Laboratories) were added. After 30 min on ice, the cells were washed twice, suspended in $0.5 \mathrm{ml}$ of HBSS, and analyzed using an Ortho Cytofluorograf Model 50$\mathrm{H}$ and Ortho 2150 computer. Fifty thousand cells were analyzed and the percentage of cells positive for any given antibody was determined by comparison to the pattern obtained with the control ascites (3).

Enumeration of Immunoglobulin-Secreting Cells. Ig secretion by cultured B lymphocytes was assessed by a modified reverse hemolytic plaque assay previously decribed $(12,13)$. MNL either were from the patient or control, or from both (in co-culture experiments) were placed in 16-mm tissue culture wells (Costar, Cambridge, MA) containing RPMI 1640 (M. A. Bioproducts) in heat-inactivated $10 \%$ fetal calf serum. PWM (Flow Laboratories, McLean, VA) or EBV (kindly provided by Dr. Michael Blaese) was added to some wells to stimulate Ig secretion. The wells were incubated at $37^{\circ} \mathrm{C}$ in $5 \% \mathrm{CO}_{2}$ for $6-8$ days and then harvested. Harvested cells were washed three times with HBSS and counted. Results were expressed as the number of plaques (Ig-SC) per million cultured MNL (13), but need interpretation in light of the manipulations of cell populations by co-culture and/or exposure of cells to irradiation or iron carbonyl. To determine if a particular manipulation had produced suppression or enhancement of Ig-SC, the actual number of plaques produced by the co-culture was divided by the predicted number of plaques and multiplied by 100 to obtain the percentage of predicted as previously described (13). Biologically significant suppression was defined as less than $30 \%$ of the predicted response, based on co-culture experiments using MNL from normal controls (13).

NK Cell Cytotoxicity and Tumor Cell-binding Studies. Effector cells from both the patient and normal donors were obtained from Ficoll-Hypaque-sedimented peripheral blood and were further purified by adherence on plastic, followed by nylon wool column fractionation $(14,15)$. The nylon wool-filtered fraction was used in all experiments. Chronic myelogenous leukemia cell line K-562 (17) was the source of target cells in all experiments. The cell line was grown as a suspension culture at $37^{\circ} \mathrm{C}$ in a $5 \%$ $\mathrm{CO}_{2}$ humidified atmosphere in RPMI 1640 (16).

The cytotoxicity assay was performed as previously described (15). Briefly, $5 \times 10^{6}$ target cells suspended in $0.5 \mathrm{ml}$ of RPMI 1640 medium supplemented with $10 \%$ fetal calf serum, HEPES buffer, and antibiotics (500 units of penicillin and $50 \mu \mathrm{g}$ of streptomycin/ml) were labeled with ${ }^{51} \mathrm{Cr}\left(\mathrm{Na}_{2}{ }^{51} \mathrm{CrO}_{4}\right)$. Fifty $\mu \mathrm{l}$ of labeled target cells $\left(10^{4}\right)$ and $100 \mu$ l of effector cells (target-toeffector cell ratio of $1: 25$ ) were then incubated in quadruplicates in round-bottomed microtiter plates (Linbro Scientific, Inc., Hamden, CT) at $37^{\circ} \mathrm{C}$ in a $5 \% \mathrm{CO}_{2}$ humified atmosphere for 3 h. The percentage of cytotoxicity was calculated according to the formula: cpm of experimental release - cpm of spontaneous release/total cpm incorporation into cells $\times 100$. Experimental 
release was obtained from cultures of ${ }^{51} \mathrm{Cr}$-labeled target cells incubated with lymphocytes, and spontaneous release from cultures containing ${ }^{51} \mathrm{Cr}$-labeled target cells alone. The spontaneous release ranged from 5 to $9 \%$. The standard error of the mean of replicates was less than $5 \%$.

A single-cell assay, described previously in detail $(14,15)$ was used to evaluate percentage of tumor-binding cells. The incubation time was $3 \mathrm{~h}$, at $37^{\circ} \mathrm{C}$ in a $5 \% \mathrm{CO}_{2}$ humidified atmosphere. The percentage of tumor-binding cells was determined by counting at least 200 lymphocytes.

\section{RESULTS}

The patient's serum Ig levels were consistently low, IgG being less than IgA or IgM (Table 1). His serum IgE levels were also quite low $(<5 \mathrm{IU} / \mathrm{ml})$ on two separate occasions (data not shown). His percentage of surface Ig-positive B cells was increased, however, on all but one occasion despite his low levels of serum Ig. Monospecific staining revealed increased percentages of IgD + cells and normal to increased percentages of IgM $^{+}$ cells. Using the reverse hemolytic plaque assay with class-specific Ig, fresh (not cultured) MNL from the patient demonstrated some spontaneous IgA-secreting lymphocytes, and a small number of IgM-secreting cells; IgG-secreting cells were essentially absent (Table 1). The patient, in addition, had undetectable serum antitoxin titers to diphtheria and tetanus (performed by the Centers for Disease Control, Atlanta, GA) both prior and subsequent to a series of three diphtheria-tetanus immunizations (data not shown). Isohemagglutinins were also undetectable (data not shown).

Previous experiments revealed that the patient's MNL failed to respond with significant blastogenesis when stimulated with mitogens, specific antigens, and in MLC (18-20, 26, 29). Subsequent studies documented persistent failure to respond to both mitogen and specific antigen stimulation but demonstrated a positive MLC response in the low normal range (Table 2). The MLC response was markedly diminished after removal of adherent cells, however. Delayed hypersensitivity skin tests remained consistently negative, even subsequent to a series of diphtheriatetanus immunizations (data not shown).

In our preliminary experiments, the patient's MNL, cultured for 6 days either without mitogen or with varying concentrations of PWM, demonstrated only rare Ig-SC, compared with the marked increase in Ig-SC following PWM exposure seen with normal control MNL. Stimulation of cultures with EBV, a T cell-independent B cell trigger, also failed to induce an increase

Table 3. In vitro responsiveness of patient's MNL to $P W M$ and $E B V$

\begin{tabular}{|c|c|c|c|c|}
\hline Date & Age & $\begin{array}{c}\text { PWM* } \\
\text { unfractionated }\end{array}$ & $\begin{array}{c}\text { PWM* } \\
\text { monocyte } \\
\text { depleted }\end{array}$ & $\begin{array}{c}\mathrm{EBV} \dagger \\
\text { unfractionated }\end{array}$ \\
\hline $6 / 10 / 80$ & 8 yr 9 mo & 63 & 1,320 & \\
\hline $7 / 22 / 80$ & $8 \mathrm{yr} 10 \mathrm{mo}$ & 5 & 311 & \\
\hline $8 / 5 / 80$ & $8 \mathrm{yr} 11 \mathrm{mo}$ & 36 & 154 & \\
\hline $9 / 9 / 80$ & 9 yr 0 mo & 436 & & 50 \\
\hline $9 / 17 / 80$ & 9 yr 0 mo & 84 & 0 & 8 \\
\hline $10 / 29 / 80$ & 9 yr $1 \mathrm{mo}$ & 10 & 98 & 11 \\
\hline \multicolumn{2}{|c|}{ Geometric mean } & 40 & 91 & 16 \\
\hline \multicolumn{2}{|c|}{ Normal rangeł } & $130-29,156$ & $12-8,174$ & $1,291-59,107$ \\
\hline
\end{tabular}

* Immunoglobulin-secreting cells $/ 10^{6}$ cultured MNL after 6 days of culture with PWM.

$\dagger$ Immunoglobulin-secreting cells $/ 10^{6}$ cultured $\mathrm{MNL}$ after 6-8 days culture with EBV.

$\ddagger 95 \%$ confidence limits (geometric mean $\times 2 \mathrm{SD}$ ).

Table 1. Immunoglobulin data in a patient with severe combined immune deficiency

\begin{tabular}{|c|c|c|c|c|c|c|c|c|c|c|c|c|}
\hline \multirow[t]{2}{*}{ Date } & \multirow[t]{2}{*}{ Age } & \multicolumn{6}{|c|}{$\begin{array}{l}\text { Unstimulated immunoglobulin- } \\
\text { secreting cells } / 10^{6} \\
\text { mononuclear cells } \\
(\mathrm{mg} / \mathrm{dl})\end{array}$} & \multicolumn{5}{|c|}{$\begin{array}{l}\text { Fluorescent anti-human } \\
\text { Ig staining (\%) }\end{array}$} \\
\hline & & IgG & IgA & IgM & IgG & IgA & IgM & IgM & IgD & IgG & IgA & Polyvalent \\
\hline $10 / 24 / 79$ & $8 \mathrm{yr} 1 \mathrm{mo}$ & 5 & 20 & 40 & & & & 13 & 18 & & & 15 \\
\hline $12 / 9 / 80$ & 9 yr 3 mo & 8 & 16 & 49 & 2 & 93 & 44 & & & & & \\
\hline $6 / 7 / 82$ & $10 \mathrm{yr} 9 \mathrm{mo}$ & 8 & 13 & 37 & & & & & & & & 49 \\
\hline $6 / 1 / 83$ & $11 \mathrm{yr} 9 \mathrm{mo}$ & 8 & 12 & 42 & & & & 30 & 42 & 1 & 6 & 41 \\
\hline \multicolumn{2}{|c|}{ Normal range* } & $631-1298$ & $70-312$ & $56-258$ & $51-1384$ & $102-2337$ & $3-358$ & $2.3-16.3$ & $1.6-14.4$ & $0.0-8.0$ & $0.0-4.7$ & $6.1-17.5$ \\
\hline
\end{tabular}

* $95 \%$ confidence limits (normal values for serum Ig levels were 9-11-year-old control subjects).

Table 2. Mitogen, specific antigen, and mixed leukocyte culture responses in patient

\begin{tabular}{|c|c|c|c|c|c|c|c|c|c|c|}
\hline Date & Age & $\begin{array}{c}\text { Unstimulated } \\
\text { response } \\
\left(\mathrm{cpm} \times 10^{3}\right)\end{array}$ & $\begin{array}{c}\text { PHA } \\
(10 \mu \mathrm{g} / \mathrm{ml}) \\
\text { net response } \\
\left(\mathrm{cpm} \times 10^{3}\right)\end{array}$ & $\begin{array}{c}\text { Con A } \\
(10 \mu \mathrm{g} / \mathrm{ml}) \\
\text { net response } \\
\left(\mathrm{cpm} \times 10^{3}\right)\end{array}$ & $\begin{array}{c}\text { PWM } \\
(1: 640) \\
\text { net response } \\
\left(\mathrm{cpm} \times 10^{3}\right)\end{array}$ & $\begin{array}{c}\text { Unstimulated } \\
\text { response } \\
\left(\mathrm{cpm} \times 10^{3}\right)\end{array}$ & $\begin{array}{c}\text { Candida } \\
(1: 100) \\
\text { net response } \\
\left(\mathrm{cpm} \times 10^{3}\right) \\
\end{array}$ & $\begin{array}{c}\text { SK-SD } \\
(1: 100) \\
\text { net response } \\
\left(\mathrm{cpm} \times 10^{3}\right) \\
\end{array}$ & $\begin{array}{c}\text { Tetanus } \\
(1: 100) \\
\text { net response } \\
\left(\mathrm{cpm} \times 10^{3}\right) \\
\end{array}$ & $\begin{array}{l}\text { MLC } \\
\text { response } \\
\text { SI* } \\
\end{array}$ \\
\hline $5 / 24 / 79$ & $7 \mathrm{yr} 8 \mathrm{mo}$ & $1.2(109) \dagger$ & $23.2(8) \dagger$ & $15.4(7) \dagger$ & $17.2(19) \dagger$ & & & & & $2.2(0.8) \ddagger$ \\
\hline $7 / 18 / 79$ & $7 \mathrm{yr} 10 \mathrm{mo}$ & & & & & $0.2(1) \dagger$ & $0.1(.4) \dagger$ & $0.2(.4) \dagger$ & & \\
\hline $8 / 13 / 79$ & $7 \mathrm{yr} 11 \mathrm{mo}$ & $0.02(10)$ & $2.4(2)$ & $0.9(1)$ & $4.5(4)$ & & & & & \\
\hline $3 / 12 / 80$ & 8 yr 6 mo & & & & & $0.02(2)$ & $0.1(2)$ & $0.02(.2)$ & $0.5(7) \dagger$ & \\
\hline $3 / 27 / 81$ & 9 yr 6 mo & $0.2(28)$ & $6.6(4)$ & $0.3(.6)$ & $5.4(9)$ & $0.4(45)$ & $0.1(4)$ & $0.2(7)$ & $0.1(5)$ & \\
\hline $6 / 7 / 82$ & $10 \mathrm{yr} 9 \mathrm{mo}$ & $0.8(26)$ & 13.5 & 6) & $9.4(7)$ & $0.2(3)$ & $0.2(2)$ & 0 & $0.2(5)$ & \\
\hline $6 / 6 / 83$ & $11 \mathrm{yr} 9 \mathrm{mo}$ & $0.2(18)$ & $9.8(5)$ & $7.3(4)$ & $5.0(3)$ & $0.3(1)$ & 0 & 0 & 0 & 3.0 \\
\hline \multicolumn{2}{|c|}{ Normal range§ } & $0-3$ & $21-235$ & $6-125$ & $34-226$ & $0-6$ & $0-13$ & $0-17$ & $0-9$ & $>2.0$ \\
\hline
\end{tabular}

* Stimulation index.

$\dagger$ Percentage of control of the same day.

$\ddagger$ Monocyte depleted.

$\S 95 \%$ confidence limits. Only the concentration of mitogens or antigens showing the largest responses of the patient are presented. 
PASCHALL ET $A L$.

Table 4. Leukocyte values in circulating blood and in $M N L$ preparations of patient

\begin{tabular}{|c|c|c|c|c|c|c|c|}
\hline \multirow[b]{2}{*}{ 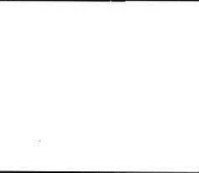 } & \multicolumn{5}{|c|}{ Circulating blood } & \multicolumn{2}{|c|}{ MNL preparations } \\
\hline & Age & $\begin{array}{c}\mathrm{WBC} / \mathrm{mm}^{3} \\
\times 10^{3}\end{array}$ & $\begin{array}{c}\text { Lymphocytes } \\
(\%)\end{array}$ & $\begin{array}{c}\text { Absolute } \\
\text { lymphocyte } \\
\text { count } / \mathrm{mm}^{3}\end{array}$ & $\begin{array}{c}\text { Monocytes } \\
\text { (\%) }\end{array}$ & $\begin{array}{c}\text { Lymphocytes } \\
\text { (\%) }\end{array}$ & $\begin{array}{c}\text { Monocytes } \\
(\%)\end{array}$ \\
\hline Mean* & $8-12 \mathrm{yr}$ & 5.6 & 7.5 & 405 & 6 & 27 & 73 \\
\hline $\mathrm{SEM} \dagger$ & & 0.3 & 0.8 & 45.5 & 1.1 & 4.5 & 5.5 \\
\hline Normal range $^{3}$ & & $4.5-14.5$ & $28-48$ & $1260-6960$ & $2-15$ & & \\
\hline
\end{tabular}

* Mean of 12 determinations.

† Standard error of the means.

$\ddagger$ Range for age 10 years ( $95 \%$ confidence limits).

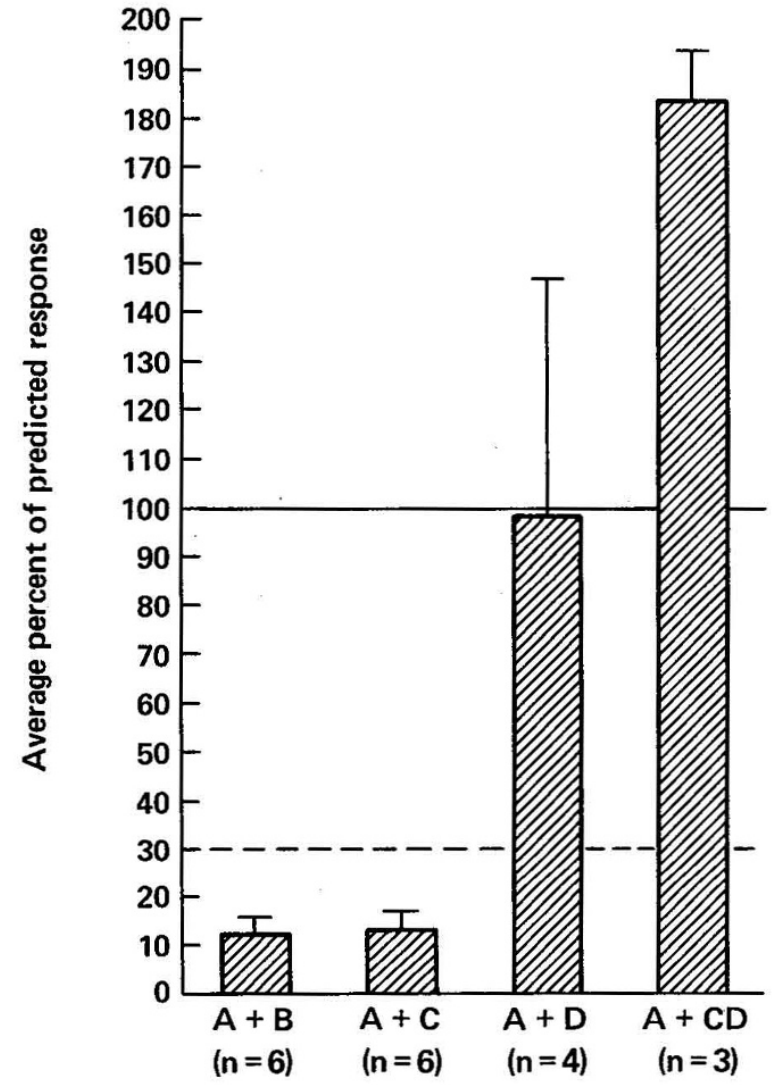

Fig. 1. Effects of co-culture of normal and SCID patient's MNL on the normal Ig-secretory response to PWM. Equal numbers of normal and patient's MNL were cultured for 6 days with PWM and the observed number of Ig-SC is expressed as an average percentage of the predicted response. Suppression of PWM-induced Ig secretion was defined as $<30 \%$ of the average predicted response. $A$, normal MNL, unfractionated; $B$, patient's MNL, unfractionated; $C$, patient's MNL, irradiated; $D$, patient's MNL, monocyte-depleted; $C D$, patient's cells, irradiated and monocyte-depleted; $n$, number of experiments. Bars show SEM.

in Ig-SC in the patient's MNL as compared to normal control MNL (Table 3).

Although the patient's mean total circulating WBC was within the normal range for age, his WBC differentials consistently demonstrated absolute lymphopenia and often showed a relative monocytosis. Preparations of his MNL also exhibited a relative excess of monocytes (Table 4). Removal of monocytes from his MNL with iron carbonyl did enhance production of Ig-SC in response to PWM, but failed to completely reverse the hyporesponsiveness of his MNL (Table 3). When equal numbers of patient and normal MNL were co-cultured with PWM in the reverse hemolytic plaque assay (Fig. 1), marked depression in numbers of Ig-SC occurred, an average percentage of $12 \%$ of the predicted response. Previous co-culture studies between unre- lated normal subjects have shown that less than $30 \%$ of the predicted response comprises biological suppression (13). With the use of radiation and/or iron carbonyl, selective subpopulations of cells from the patient's MNL were removed or inactivated prior to co-culture. Irradiation of the patient's MNL (which inactivates B cells and suppressor T cells) prior to co-culture with normal MNL did not alter the suppression of Ig-SC in co-culture. Likewise, the addition of indomethacin, an inhibitor of prostaglandin synthesis, did not reverse the suppression of Ig secretion, suggesting little or no role for prostaglandins in the observed suppression (data not shown). Removal of monocytes from the patient's MNL with iron carbonyl prior to co-culture, however, completely reversed the suppression of Ig-SC, producing an average percentage of $99 \%$ of the predicted response. The combination of removal of monocytes and inactivation of radiosensitive cell lines from the patient's MNL prior to co-culture produced a marked enhancement in the number of Ig-SC, an average percentage of $184 \%$ of the predicted response.

Subpopulations of the patient's MNL were characterized using monoclonal antibodies in addition to more classic techniques (Table 5). The percentages of B lymphocytes $(\mathrm{B} 1+)$ were strikingly elevated above the normal range while the percentages of total T lymphocytes (T3+) were subnormal. The percentages of both helper/inducer T cells (T4+) and suppressor/cytotoxic T cells (T8+) were also subnormal except on two occasions when the percentages of $\mathrm{T} 8+$ cells were in the low normal range. The T4:T8 ratio varied considerably $(1.2-5.5)$ throughout the time the patient was studied.

The patient's NK cell function was evaluated on two separate occasions using both the ${ }^{51} \mathrm{Cr}$ release assay and the single-cell assay to measure the percentage of tumor-NK cell binding (Table 6). The patient exhibited extremely low percentages of NK cell cytotoxicity as compared to each of the normal donors. His percentage of tumor-binding cells was, however, comparative to that of the normal donor's on both occasions.

\section{DISCUSSION AND CONCLUSION}

This patient continues to exhibit profound defects in immunological function. He is in that subpopulation of individuals with SCID who are able to secrete small quantities of $\mathrm{Ig}$ as manifested by his low serum Ig levels and few numbers of Igsecreting lymphocytes in in vitro cultures. He was unable, however, to produce any specific antibody against antigens to which he has been repeatedly exposed such as diphtheria and tetanus. Despite increased percentages of B cells, the normal response of increased Ig secretion in response to PWM and EBV was severely impaired.

Cellular immunity was also greatly depressed, demonstrated by poor responses to mitogens and specific antigens and by the absence of any positive delayed hypersensitivity skin tests. Partial T-cell function was exemplified by lymphocyte reactivity in the MLC test, a finding recorded previously in a few children with variant forms of $\operatorname{SCID}(6,10,22)$.

The patient's ability to produce some Ig and to respond in the MLC test raised the question of whether his cells lacked proper 
Table 5. Characteristics of mononuclear cell subpopulations

\begin{tabular}{|c|c|c|c|c|c|c|c|c|c|c|c|}
\hline \multicolumn{5}{|c|}{$\begin{array}{c}\text { E rosettes } \\
(\%)\end{array}$} & & & & & & & \\
\hline $7 / 18 / 79$ & \multicolumn{2}{|c|}{$7 \mathrm{yr} 10 \mathrm{mo}$} & \multicolumn{2}{|c|}{5.0} & & & & & & & \\
\hline $8 / 13 / 79$ & \multirow{2}{*}{\multicolumn{2}{|c|}{$\begin{array}{l}7 \text { yr } 11 \mathrm{mo} \\
9 \text { yr } 6 \mathrm{mo}\end{array}$}} & \multicolumn{2}{|c|}{6.9} & & & & & & & \\
\hline $3 / 27 / 81$ & & & \multicolumn{2}{|c|}{15.8} & & & & & & & \\
\hline $6 / 7 / 82$ & \multicolumn{2}{|c|}{$10 \mathrm{yr} 9 \mathrm{mo}$} & \multirow{2}{*}{\multicolumn{2}{|c|}{$\begin{array}{r}4.0 \\
15.1\end{array}$}} & & & & & & & \\
\hline $6 / 1 / 83$ & \multicolumn{2}{|c|}{11 yr $9 \mathrm{mo}$} & & & & & & & & & \\
\hline \multicolumn{2}{|l|}{ Normal range } & \multicolumn{3}{|c|}{$43.4-81.0$} & & & & & & & \\
\hline B. Date & Age & $\% \mathrm{~T} 11$ & $\% \mathrm{~T} 3$ & $\% \mathrm{~T} 4$ & $\% \mathrm{~T} 8$ & $\% \mathrm{~T} 6$ & $\% \mathrm{~T} 10$ & $\mathrm{~T} 4: \mathrm{T} 8$ & \%Ia1 & $\% \mathrm{~B} 1$ & $\%$ M1 \\
\hline $5 / 20 / 81$ & $9 \mathrm{yr} 8 \mathrm{mo}$ & & 30.9 & 19.3 & 15.3 & & & 1.3 & 47.7 & & 0 \\
\hline $7 / 21 / 81$ & $9 \mathrm{yr} 10 \mathrm{mo}$ & & 40.4 & 21.1 & 17.7 & & & 1.2 & 24.9 & 17.7 & 13.4 \\
\hline $10 / 26 / 81$ & $10 \mathrm{yr} 1 \mathrm{mo}$ & 22.7 & $25: 0$ & 14.3 & 3.7 & & & 3.9 & 49.3 & 42.2 & 6.2 \\
\hline $12 / 16 / 81$ & $10 \mathrm{yr} 3 \mathrm{mo}$ & & 12.9 & 5.5 & 1.0 & 1.1 & & 5.5 & 60.1 & 32.6 & 25.0 \\
\hline $6 / 7 / 83$ & $11 \mathrm{yr} 9 \mathrm{mo}$ & 11.6 & 11.0 & 12.7 & 3.8 & 0 & 13.1 & 3.3 & 68.1 & 45.4 & 29.7 \\
\hline Normal* range & & $54-97$ & $60-85$ & $45-60$ & $15-25$ & $0-2$ & $3-5$ & $1.5-3.5$ & $5-20$ & $5-10$ & $10-25$ \\
\hline
\end{tabular}

* $95 \%$ confidence limits.

Table 6. NK cell cytotoxic potential and tumor-binding properties in patient

\begin{tabular}{|c|c|c|c|c|c|}
\hline \multirow[b]{2}{*}{ Date } & \multirow[b]{2}{*}{ Age } & \multicolumn{2}{|c|}{$\begin{array}{l}\% \text { of cytotoxicity* } \\
\left({ }^{51} \mathrm{Cr} \text { release assay }\right)\end{array}$} & \multicolumn{2}{|c|}{$\begin{array}{c}\% \text { of tumor-binding } \\
\text { cells } \dagger\end{array}$} \\
\hline & & Patient & $\begin{array}{l}\text { Normal } \\
\text { donor } \ddagger\end{array}$ & Patient & $\begin{array}{c}\text { Nor- } \\
\text { mal } \\
\text { donor } \ddagger\end{array}$ \\
\hline $12 / 16 / 82$ & $11 \mathrm{yr} 3 \mathrm{mo}$ & 1.2 & 21.3 & 9.5 & 8.1 \\
\hline $1 / 17 / 83$ & $11 \mathrm{yr} 4 \mathrm{mo}$ & 0.1 & 30.4 & 8.0 & 7.5 \\
\hline
\end{tabular}

* Target-to-effector cell ratio was 1:25.

$\dagger$ Target-to-effector cell ratio was 1:1.

$\ddagger$ The normal donor for the experiments on $1 / 17 / 83$ was not the same donor as for $12 / 16 / 82$.

helper function and/or had excessive suppressor influences preventing normal $B$ and $T$ cell function. The observation that removal of monocytes from his MNL increased but did not normalize Ig secretion in response to PWM suggested that a relative monocyte excess might contribute to his B cell hyporesponsiveness, but that his B cells were intrinsically defective as well.

Co-cultured experiments demonstrated that the patient's cells markedly suppressed pokeweed-stimulated Ig secretion in normal controls. We attempted to characterize further this excessive suppressor effect by selectively removing or inactivating subpopulations of the patient's MNL prior to co-culture. When monocytes were removed from his MNL, suppression was totally reversed, implying that excessive suppressor monocyte activity, probably secondary to relatively increased numbers of monocytes, accounted for his dramatic suppressor function. Other investigators have reported previously that in vitro lymphocyte responses may be significantly affected by the relative proportions of monocytes present $(8,11,23)$. The patient's response in the MLC test was diminished after removal of monocytes, however, indicating an absence of suppressor monocyte activity on $\mathrm{T}$ cell proliferative responses. Inactivation of the suppressor $\mathrm{T}$ cell subpopulation by irradiation did not alter suppression of Ig secretion in the patient's cells although it did enhance Ig secretion in monocyte-depleted co-cultures. It therefore does not seem likely that suppressor $\mathrm{T}$ cells contributed significantly to the patient's excessive suppressor function. The fact that both the putative helper/inducer (T4+) and suppressor/cytotoxic (T8+) subpopulations were generally decreased in the patient, with his T4:T8 ratio ranging from subnormal to elevated values, lends further support to the notion that neither a relative decrease in helper T cells nor a relative increase in suppressor $\mathrm{T}$ cells contributed to his B lymphocyte hyporesponsiveness.

NK cell activity was markedly abnormal in the patient as manifested by his extremely low percentages of NK cell cytotoxicity. The results of the single-cell assay suggested that his NK cells had normal tumor-binding properties. Thus, it appears that the patient's defective NK cell activity stems from decreased killing of already bound tumor targets and not from decreased tumor-NK cell binding.

Serial studies were performed to assess immunologic function in a patient with SCID who is unique in having been maintained in a gnotobiotic environment for over 12 years. Since SCID encompasses a heterogeneous group of disorders, we attempted to elucidate and characterize his specific immunological deficits. This patient's immunodeficiency appears to be secondary to at least decreased numbers of T and B cells, an intrinsic defect in $B$ cells, excessive suppressor monocyte activity on B cell function, and defective NK cell killing.

\section{REFERENCES AND NOTES}

1. Atwater JS, Tomasi TB 1978 Suppressor cells and IgA deficiency. Clin Immunol Immunopathol 9:379

2. Boyum A 1968 Separation of leukocytes from blood and bone marrow. Scand J Clin Lab Invest [Suppl 97] 21:31

3. Breard J, Reinherz EL, Kung TC, Goldstein G, Schlossman SF 1980 A monoclonal antibody reactive with human peripheral blood monocytes. J Immunol 124:1943

4. Buckley RH, Gilbertsen RB, Schiff RI, Ferreiera E, Sanai SO, Waldmann TA 1976 Heterogeneity of lymphocyte subpopulations in severe combined immunodeficiency: evidence against a stem cell defect. J Clin Invest 58:130

5. Eisen SA, Wedner $\mathrm{HH}$, Parker CW 1972 Isolation of pure human peripheral blood T lymphocytes using nylon wool columns. Immunol Commun 1:571

7. Geha RS 1976 Is the B-cell abnormality secondary to T-cell abnormality in severe combined immunodeficiency? Clin Immunol Immunopathol 6:102

6. Fischer A, Durandy A, Virelizier JL, DeSaint Basile G, Lagrue A, Reinherz E, Schlossman S, Griscelli C 1981 Severe combined immunodeficiency with quantitatively normal but abnormally differentiated $\Upsilon$ lymphocytes. J Pediatr 99:261

8. Gmelig-Meyling F, Waldman TA 1981 Human B cell activation in vitro: augmentation and suppression by monocytes of the immunoglobulin production induced by various B cell stimulants. J Immunol 126:529

9. Greaves MF 1970 Biological effects of anti-immunoglobulins. Evidence for immunoglobulin receptors on " $\mathrm{T}$ " and " $\mathrm{B}$ " lymphocytes. Transplant Rev $5: 45$

10. Karol RA, Eng J, Cooper JB, Dennison DK, Sawyer MK, Lawrence EC Marcus DM, Shearer WT 1983 Imbalances in subsets of T lymphocytes in an inbred pedigree with Omenn's syndrome. Clin Immunol Immunopathol 27:412

11. Laughter AH, Twomey JJ 1977 Suppression of lymphoproliferation by high concentrations of normal human mononuclear leukocytes. J Immunol 119:173

12. Lawrence EC, Blaese RM, Martin RR, Stevens PM 1978 Immunoglobulin secreting cells in normal human bronchial lavage fluids. J Clin Invest 62:832

13. Lawrence EC, Theodore BJ, Teague RB, Gottlieb MS 1982 Defective immu- 
noglobulin secretion in response to pokeweed mitogen in sarcoidosis. Clin Exp Immunol 49:96

14. Lotzova E, Savary CA, Keating MJ 1983 Studies on the mechanism of defective natural killing in leukemia-diseased patients. Exp Hematol 10:83

15. Lotzova E, Savary CA, Gutterman JU, Hersh EM 1982 Modulation of natural killer cells-mediated cytotoxicity by partially purified and cloned interferon$\alpha$. Cancer Res 42:2480

16. Lotzova E, McCredie KB, Muesse L, Dicke KA, Freireich EJ 1979 Natural killer cells in man: their possible involvement in leukemia and bone marrow transplantation. In: Experimental Hematology Today. Springer-Verlag, New York, pp 207-213

17. Lozzio CB, Lozzio BB 1972 Human chronic myelogenous leukemia cell line with positive Philadelphia chromosome. Blood 45:321

18. Mackler BF, O'Neill PA 1979 T-lymphocyte induction of non-T-cell-mediated nonspecific cytotoxicity. II. A clinical study of a severe combined immunodeficiency patient maintained in gnotobiotic environment. Clin Immunol Immunopathol 12:358

19. Mukhopadhyay N, Richie E, Montgomery JR, Wilson R, Fernbach DJ, South MA 1976 Peripheral blood T and B cell characteristics in a patient with severe combined immunodeficiency (SCID) maintained in a gnotobiotic environment. Exp Hematol 4:1

20. Mukhopadhyay N, Richie E, Mackler BF, Montgomery JR, Wilson R, Fernbach DJ, South MA 1978 A longitudinal study of T and B lymphocytes from a three-year-old patient with severe combined immunodeficiency (SCID) in gnotobiotic protection. Exp Hematol 6:129

21. Pahwa SG, Pahwa RN, Good RA 1980 Heterogeneity of B lymphocyte differentiation in severe combined immunodeficiency disease. J Clin Immunol 66:534

22. Reinherz EL, Cooper MD, Schlossman SF, Rosen FS 1981 Abnormalities of $\mathrm{T}$ cell maturation and regulation in human beings with immunodeficiency diseases. J Clin Invest 68:699

23. Rosenberg SA, Lipsky PE 1979 Monocyte dependence of pokeweed mitogeninduced differentiation of immunoglobulin-secreting cells from human peripheral blood mononuclear cells. J Immunol 122:926
24. Seeger RC, Robins RA, Stevens RH, Klein RB, Waldman OJ, Zeltzer PM, Kessler SW 1976 Severe combined immunodeficiency with B lymphocytes: in vitro correlation of defective immunoglobulin production by addition of normal T lymphocytes. Clin Exp Immunol 26:1

25. Siegal FP, Siegal M, Good RA 1976 Suppression of B cell differentiation by leukocytes from hypogammaglobulinemic patients. J Clin Immunol 58:109

26. South MA, Montgomery JR, Richie E, Mukhopadhyay N, Criswell BS, Mackle BF, DeFasio SR, Bealmear P, Heim LR, Trentin JJ, Dressman GR, O'Neill P 1977 A special report: four-year study of a boy with combined immune deficiency maintained in strict reverse isolation from birth. IV. Immunologic studies. Pediatr Res 11:71

27. Waldmann TA, Broder S, Blaese RM, Durm M, Blackman M, Strober W 1974 Role of suppressor $\mathrm{T}$ cells in pathogenesis of common variable hypogammaglobulinemia. Lancet 2:609

28. Waldmann TA, Strober W, Baese RM $1980 \mathrm{~T}$ and B cell immunodeficiency diseases. In: Parker CW (ed) Clinical Immunology, Chap 11. WB Saunders Company, Philadelphia

29. Williamson AP, Montgomery JR, South MA, Wilson R 1977 A special report: four year study of a boy with combined immunodeficiency maintained in strict reverse isolation from birth. Pediatr Res 11:63

30. Wybran J, Carr MC, Fudenberg HH 1972 The human rosette-forming cells as a marker of a population of thymus-derived cells. J Clin Invest 51:2537

31. We thank Dr. Ralph D. Feigin for a critical review of the manuscript, nurses Brynn Holcombe, Donna Aldrich, and Lynn Franklin for obtaining blood specimens and maintaining the patient's isolator system, and Ms. Peggy Jackson for preparation of the manuscript.

32. This work was supported by General Clinical Research Center Grant RR00188 , the John P. McGovern Foundation, and a special fund from Texas Children's Hospital.

33. Correspondence should be addressed to Dr. William T. Shearer, Allergy and Immunology Section, Department of Pediatrics, Baylor College of Medicine, 12000 Moursund Avenue, Houston, TX 77030.

34. Received for publication January 9, 1984.

\title{
Prevention of Neonatal Hyperbilirubinemia in Rhesus Monkeys by Tin-protoporphyrin
}

\author{
CHARLES E. CORNELIUS ${ }^{(21)}$ AND PAMELA A. RODGERS \\ California Primate Research Center, University of California, Davis, California USA
}

\section{Summary}

Rhesus monkey infants were injected subcutaneously at birth with 12 to $100 \mu \mathrm{mol}$ of tin-protoporphyrin IX, a competitive inhibitor of microsomal heme oxygenase. The elevated unconjugated serum bilirubin levels of the neonates receiving this metalloporphyrin rapidly declined to near adult levels by 24-30 h. Control neonates which received an injection of saline exhibited normal physiologic hyperbilirubinemias of from 3-6 mg/dl by 12-24 $\mathrm{h}$ as expected. These studies establish the effectiveness of tin-protoporphyrin IX in depressing bilirubin production and preventing physiologic hyperbilirubinemia in simian neonates. Two of six animals receiving the metalloporphyrin exhibited signs of toxicity.

Physiologic jaundice in the newborn human infant has been the subject of intensive investigation for many years $(10,13)$. Studies have been generally limited to the measurement of single physiologic mechanisms in neonates; this has made interpretations difficult as to the effects of bilirubin overload (10), deficient hepatic UDP-glucuronyltransferase activity $(4,7)$, and defective hepatocellular uptake of unconjugated bilirubin $(8,14)$. Due to the absence of physiologic jaundice in the guinea pig (8) and the presence of only a transient hyperbilirubinemia $(<1 \mathrm{mg} / \mathrm{dl})$ in neonatal rats (6), the newborn rhesus monkey which exhibits a marked physiologic hyperbilirubinemia appears to be the animal model of choice for future studies (10).

Rhesus monkey neonates exhibit a two-phase pattern of physiologic unconjugated hyperbilirubinemia similar to that observed in humans, although of shorter duration (10). It has also been observed that newborn rhesus monkeys excrete bilirubin conjugates into bile at rates 5 -fold greater than those of mature animals $(9,10)$. The increased load of bilirubin presented to the human neonate's liver could possibly occur from increased bilirubin synthesis (16) and/or augmented enteric reabsorption of bilirubin (18). Interruption of the enterohepatic circulation of bilirubin through bile diversion from the intestine significantly reduces the bilirubin load presented to the liver (18). It has been postulated that the bilirubin monoglucuronide excreted by the neonate into the intestine $(2,3)$ may be more easily deconjugated and reabsorbed into the enterohepatic circulation than is bilirubin 